\title{
PUBLIC POLICY AND THE POLITICAL CRISIS IN THE CONFLICT OF LAWS
}

\author{
By ARTHUR NUSSBAUM $\dagger$
}

\section{The Actual Use of the Public Policy Coscept}

Since the appearance of Professor Lorenzen's pioneering studies on the conflict of laws, ${ }^{1}$ that is, during approximately the last two decades, many of the basic problems of the subject have received abundant and illuminative investigation in this country. Yet the significance of one important problem, that of public policy, which has recently come to the fore as a result of the world political crisis, with its accompanying incongruities and tensions in respect to the various municipal laws, seems hardly to have been recognized in recent legal literature. The purpose of the present Article is to suggest the necessity of a reexamination of the entire doctrine in the light of recent developments.

Although utilization of the public policy concept in Anglo-American law is wide and varied, much confusion can be aroided if the various legal uses of this concept are kept separate. One such use is affirmative: public policy is relied upon in order to solve doubts as to the interpretation of legal rules. This affirmative or interpretative function is particularly important in respect to statutory provisions of a penal character. $^{2}$ Two other uses of the concept are negative or limitative. (1) Public policy limits freedom of contracts, invalidating, for instance, yellow-dog contracts or agreements in restraint of trade. ${ }^{3}$ Comparable to the contract use is the use of public policy in invalidating testamentary provisions, for instance; because of the presence of illicit conditions. ${ }^{4}$

$\doteqdot$ Research Professor of Public Law, Columbia University.

1. One might think principally of The Conmict of Laws Rechtmig to Bilus arod Notes (1919) and of such articles as The Reneroi Doctrine in the Conflict of Lati's (1918) 27 Yale L. J. 509, The Theory of Qualifications and the Conflict of Lazis (1924) 33 Yale L. J. 736, Territoriality, Public Policy and the Conflict of Lazts (1924) 33 Yale L. J. 736. Some of Professor Lorenzen's articles were published before the Vorld War. See The Renvoi Theory and the Application of Forcign Law (1910) 10 CoL. L. REv. 190, 327, and The Validity of Wills, Deeds and Contracts as Regards Form in the Conflict of Lazes (1911) 20 Y ALE L. J. 427.

2. E.g., People v. Hawkins, 157 N. Y. 1, 12 (1878); State v. Brown, 47 Ohio St. $102,109,23$ N. E. 747,749 (1S90); Sweeney v. Hunter, 145 Pa. 363,22 Atl. 653 (1S91); Chaffee v. Farmers' Corp., 39 N. D. 585, 593, 168 N. WT. 616, 618 (1918); Mogul v. MicGregor, [1892] A. C. 25. The affirmative use of public policy, however, is not limited to cases of this type. See, e.g., the utterance of Mr. Justice Holmes in Tue Cosnsos: LAW (1881) 35.

3. See Greenhood, The Doctrine of Purlic Policy as the Law as Conmacts (18s6), and Gellhorn, Contracts and Public Policy (1935) 35 Con. L. Rev. 679.

4. Mrainly by invalidating certain legacy clauses and thereby the legacies themeslves. For American cases, see Atkinsox, Haxinook os the LAw of Wurs (1937) 351. 
(2) Public policy furthermore limits the application of foreign law (and the recognition of foreign judgments ${ }^{5}$ ).

This Article is solely concerned with the last, the "conflicts" function of public policy.

It has invariably been assumed in this country, even by the most liberal courts, that application of foreign law, though warranted under the general conflict of laws rules of the forum, may nevertheless be disregarded on the ground that such application would run counter to the public policy of that forum. Thus, when the New York Court of Appeals, in Dougherty $v$. Equitable Life Assurance Society, ${ }^{\circ}$ deemed itself bound to espouse the destruction of life insurance policies under the law of Soviet Russia, the court still maintained that American judges were not compelled to give effect to foreign laws contrary to our public policy. ${ }^{\top}$

The conflicts use of public policy, or in continental terminology, "ordre public," is a world-wide phenomenon. Significantly enough, there is, in "international private law," scarcely a rule so common as the reservation

5. See p. 1056 infra.

6. 266 N. Y. 71, 193 N. E. 897 (1934).

7. De Brimont v. Penniman, 7 Fed. Cas. 309 (C. C. S. D. N. Y. 1873) is generally and properly considered as based on public policy although this term is not used in the opinion (which also employs, without clear distinction, another line of reasoning, sce note 74 infra). See In re Macartney, 1 Ch. D. 522 (1921). Frequently the public policy rule is enunciated by the formula that "comity" does not require recognition of the forcign law in question. See, c.g., Petrogradsky Mejdunarodny Kommercheskey Bank v. Nat. City Bank, 253 N. Y. 23, 35, 170 N. E. 479, 483 (1930) ; Flagg v. Baldwin, 38 N. J. Eq. 219 (1884); Saxby v. Fulton, [1909] 2 K. B. 208.

In listing pertinent cases, one must keep in mind possible differences in terminology. The rule of public policy may be used without mention of the term [Siegmann v. Meyer, 100 F. (2d) 367 (C. C. A. 2d, 1938)] or the rule may appear in the guise of a novel juridical theory. Both forms were employed in the recent federal case, supra. The wife of a New York resident had assaulted the plaintiff in Florida. The plaintiff brought an action against the husband, who had not been in Florida, to recover damages for his wife's tort. Suit was brought in a federal district court in New York. The lower court dismissed the claim, upon the ground that if the Florida law was applicable, the rule invoked by the plaintiff would be "too repugnant to the law of New York to be tolerated in that state." The decision is a clear application of the public policy rule, although that term was not employed.

The Circuit Court of Appeals for the Second Circuit, through Judge Learned Hand, affirmed the judgment, basing the decision, however, upon the "local law" theory that a New York court can enforce only New York rights and liabilities. Under the "local law" theory, foreign law is never binding upon the courts of the forum, although it may, as Judge Hand puts it, furnish an appropriate "model" for the liability to be imposed by the New York law. In the particular case, however, Judge Hand held that the Florida "model" under consideration, which charges the absent and non-resident husband with liability, could not be "accepted as a standard" in New York. "We have not been able to find any similar case, and it is hard to imagine any other situation which would present it." Although obscured by the rarely-used local law theory, this is really a decision based upon the public policy doctrine. 
that, in appropriate cases, the foreign law will be abandoned and recourse had to the lex fori. Historically, the rule developed earlier in AngloSaxon than in continental law. The contracts use of the public policy concept can be traced back to the fifteenth century, ${ }^{8}$ and its conflicts use to the eighteenth century, ${ }^{9}$ whereas the continental public policy doctrine took its rise in the middle of the nineteenth century. ${ }^{20}$ But despite the longer tradition, the range of application of the conflicts use of public policy is somewhat narrower in modern Anglo-American, and particularly in American law.

One reason for this difference is that Anglo-American law as to capacity, marital status, inheritance and other "personal" relations is principally determined by the domicil of the parties, while under continental learning such law is determined by their nationality. Since law suits are usually conducted in the domicil of the defendant, there is much less opportunity, under the domicil rule, for the application of foreign law. Another factor in the trend, appearing particularly in American law, is the expansion of the concept that "procedure" is always governed by the lex fori. Under the procedural theory, important chapters of private law, such as the statute of limitations, ${ }^{11}$ damages, ${ }^{12}$ conversion of foreign money ${ }^{13}$ and receivership ${ }^{14}$ have more or less been placed under the control of that law. Furthermore, some corollaries of the public policy notion have become independent conflict of laws propositions in Anglo-American law, i.e., non-recognition of foreign penal laws ${ }^{15}$ and impossibility of performance due to foreign law. ${ }^{18}$ Moreover, so far as this country is concerned, there is a relative paucity of international

8. See Knight, Public Policy in En!lish Laa' (1922) 38 L. Q. Rev. 207.

9. Boucher v. Lawson, Cas. T. Hard. 85 and 194, 95 Eng. Rep. 53 and 125 (1735); Robinson v. Bland, 2 Burr. 1077, 1084, 97 Eng. Rep. 717, 721 (1760); Falliot v. Ogden, 3 T. R. 726, 100 Eng. Rep. $\$ 25$ (1789).

10. By Savigny's discourse on the "limits, in space, of rules on legal relations" in his Systear of Present Roman Law (1840) (Systear des Heltrge: Römiscae: Rechts) translated under the title Treitise ox the CoNfLict of Low's AxD tue Lisits of Thetr Operation in Respect of Time ann Space (Guthrie trans., 2d ed. 1830). Savigny does not use the term "ordre public," but he possesses its concention. On the history of that term, see note 101 infra.

11. See Stungerg, Principles of Conflict of Lails (1939).

12. See Stuarberg, op. cit. supra note 11, at 146 .

13. Nussbaun, MONEy IN the LAW (1939) 427, 464.

14. One has to think more particularly of the rule which denies forcign receivers authority within the forum. STUMIBERG, op. cit. supra note 11, at 424.

15. See StuMrarg, op. cit. supra note 11, at 953.

16. Central Hanover Bank \& Trust Co. v. Siemens \& Halske Actiengesellschait, 15 F. Supp. 927 (S. D. N. Y. 1936), aff'd, S4 F. (2d) 993 (C. C. A. 2d, 1936), cert. denicd, 299 U. S. 585 (1936); Vainetta Velvet Co. v. Kakana Ka, Ltd, 256 App. Div. 341, 10 N. Y.S. (2d) 270 (1939); Kleinwort, Sons \& Co. v. Ungarische Bummolle Industrie, 55 T. L. R. 814 (C. A. 1939), and earlier cases cited in these decisions. 
litigation. ${ }^{17}$ American conflicts cases are, in their overwhelming majority, interstate in character and therefore less affinitive to public policy problems which primarily originate in international relations. Nevertheless, the importance of the matter is on the ascendant in American as well as in English law.

\section{Analysis of the Anrerican Public Policy Doctrine}

The continental public policy theory stems from the proposition that, in each legal system, there are certain norms which the forum should not dispense with in favor of a divergent foreign law: for instance, norms of monogamy, of prohibition of slavery and of unenforceability of gambling contracts. ${ }^{18}$ Much labor has been spent to define these "prohibitive" norms and to secure tests for fair distinction and classification, ${ }^{10}$ but it is familiar learning that these attempts have failed. Yet there may be norms suggested by the original public policy doctrine which the forum will carry through against any foreign law applicable, in a particular instance, under general conflicts rules. An early English decision suggested a frequently repeated instance by hypothetically referring to a prostitute's suit for her wages which an English court never would allow, although the claim be recognized by foreign law. ${ }^{20}$ Such a foreign law probably does not exist, ${ }^{21}$ but there are a few cases which seem to indicate that the forum would consider prohibitions against the enforcement of certain contracts, such as gaming and usury contracts, as absolutely binding upon the court notwithstanding any foreign law to the contrary. ${ }^{22}$ It may even be imagined that under the stress of present political world crises certain principles of humanity, in the spirit of the Declaration of Independence, would be considered "inalienable," regardless of foreign law.

In general, however, a foreign law which in itself is repugnant to the forum will be accorded recognition where the repercussion of that law upon the forum is remote and unharmful..$^{23}$ Although the forum abhors

17. Even the absolute number of international conflicts cases is considerably less than one should expect considering the size and importance of the United States' foreign trade. This phenomenon cannot be considered here.

18. This is particularly the idea advanced by Savigny in the discourse cited supra note 10 .

19. Knapp, La Notion de L'Ordre Public dans les Conflicts de Lois (Thesis, Neufchatel, 1933) gives a helpful survey of that literature.

20. Robinson v. Bland, 2 Burr. 1077, 1084, 97 Eng. Rep. 717, 721 (1760).

21. Goodrice, Conflict of Laws (2d ed. 1938) 257 , n. 3 , states that no actual instance of such a suit has been found.

22. See note 36 infra.

23. For writings mostly continental on this problem, see Knapp, op. cit. supra note 19, at 51 et séq. Cf. also Lewald, La Reglémentation De L'Ordre Public Sur lc Terrain Des Traites Diplomatiques (1928) 23 REv. Drotr INr. PrivE 149. 
polygamy, it will, nevertheless, recognize the legitimacy of a child born abroad in a polygamous marriage entered into and valid abroad.2: All depends on the circumstances, or, more precisely, on the importance of the "contacts" of the case with the territory of the forum. Only an actual, strong and adverse ${ }^{25}$ interest of the forum will prompt the court to refuse the application of the foreign law that would govern under general conflict of laws rules. This is the doctrine of the "relativity" of public policy or "ordre public," or the doctrine of relativity according to contacts, as distinguished from the comparatively less important relativity of public policy in space and time, which latter simply means that views on public policy change with territories and epochs.

Courts all over the world act, on the whole, in accord with the relativity principle, although in continental cases the language may sometimes be adversely influenced by misleading conceptions, drawn from theoretical controversies on the nature of public policy. ${ }^{2 \pi}$ The absence of such controversies has been advantageous to Anglo-American developments. Using the traditional technique of the common law, the English and American courts have succeeded in building up, without misleading formulas, a flexible and intrinsically sound public policy doctrine, to which the relativity of public policy is a matter of course. ${ }^{28}$

The state of Anglo-American juristic theory on public policy is less satisfactory, however. Dependence of the theory of public policy on contacts with the forum - the "relativity ratione materiae" - has hardly been recognized, ${ }^{29}$ although this point is actually of great importance. It was referred to in a comment ${ }^{30}$ on the recent New York case of Holzer v. Deutsche Reichsbahngesellschaft. In that case, a German non-Aryan, an employee of the German Railway Company, had been dismissed under the non-Aryan laws of 1933, before the expiration of his employment contract. The lower court had allowed the employee's claim for indemnification, disregarding the non-Aryan law for reasons

24. See ron Bar, The Theory and Practice of Private Intermational Law (1892) 96.

25. See Restatenent, Cosflict of Laws (1934) $\$ 612$.

26. Relativity in time is referred to, e.g., in Straus v. Canadian P. Ry., 254 X. Y. $407,413,105$ N. E. 653,655 (1914) (regarding the changes in the law on carriers' liatility) ; Berkovitz v. Arbib \& Houlberg, 230 N. Y. 261, 130 N. E. $28 s$ (1921) (regarding the changes in the law of arbitration).

27. For German instances, see Nussbium, Deutsches Intersantroizales PrusatRECHT (1932) 65 , п. 4.

28. Practically all of the English and American public policy cases exhibit a "weighing" of the contacts involved. See particularly note 35 infra. An earlier and forgotten case of this type is Forbes v. Scannel, 13 Cal. 242, 276 (1859).

29. Thus not even in Healy's lectures, Théoric gentrale de l'ordre pnblic, 9 Fingue, ACADÉNIE dE DROIT INT., RECUEII DES COURS (1925) 407, 411-557.

30. Comment (1936) 45 YaLE L. J. 1463, 1470. See (1937) 23 V.. L. Rev. 28S, 295; (1938) 38 CoL. L. REv. 1490, 1492. 
of American public policy, ${ }^{31}$ but the Court of Appeals reversed in an opinion strongly emphasizing the lack of contacts warranting the use of the public policy rule. ${ }^{32}$ The decision, the substance of which shall not be discussed here, is understandable only in terms of the relativity doctrine. $^{33}$ This has been contested by one commentator ${ }^{34}$ who, however, did not consider the court's unmistakable language. The commentator asserted that there are New York cases inconsistent with an approach based on contacts, but the instances given are unconvincing. ${ }^{35}$ Moreover, it is not inconsistent with the relativity doctrine to hold certain foreign rules so repugnant to the policy of the forum that no recognition should be given to them regardless of contacts. However, it is difficult to find specific instances. There may be an important contact justifying the use of public policy, although the court's reasoning does not explicitly refer to the existence of that contact. ${ }^{36}$

31. Holzer v. Deutsche Reichsbahngesellschaft, 159 Misc. 830, 290 N. Y. Supp. 181 (Sup. Ct. 1936).

32. Holzer v. Deutsche Reichsbahngesellschaft, 277 N. Y. 474,14 N. E. (2d) 798 (1938).

33. The court relied mainly on the following sentence from the Doughcrty case, supra note $6:$ :. . . . it cannot be against the public policy of this state to hold nationals to the contracts which they have made in their own country to be performed there according to the laws of that country." Dougherty v. Equitable Life Ass. Soc., 266 N. Y. 71, 90, 193 N. E. 897,903 (1934).

34. See (1938) 38 Col. L. Rev. 1490, 1493, n. 17.

35. Barth v. Backus, 140 N. Y. 230, 35 N. E. 425 (1893), denied effect on New York property of an involuntary assignment of property under Wisconsin bankruptcy laws. This is a self-sustained rule of conflicts of laws, now adopted by the Restatement, CoNFLICrS OF LAws (1934) §264. Meacham v. Jamestown R. R., 211 N. Y. 346, 105 N. E. 653 (1914), refused to recognize the validity of a Pennsylvania agreement to arbitrate. While Hogan, J., gave public policy as a reason, Judge Cardozo in a convincing concurring decision pointed out that arbitration is procedural. Moreover, the defendant being a New York corporation, there were sufficient contacts with the forum. In Strauss v. Canadian Pac. Ry., 254 N. Y. 407, 173 N. E. 560 (1930), an exculpatory clause in a foreign through bill of lading was held invalid under New York law. The strong contact with the forum was manifest since the bill of lading called for delivery in New York.

A commentator further asserts that three other cases which might be explained on the contact basis are unclear, [(1938) 38 CoL. L. Rev. 1490, 1493, n. 18], but gives no reason for this criticism. In reality most of the cases confirm the relativity rule, with the exception of Russian Reinsurance Co. v. Stoddard, 240 N. Y. 149, 142 N. E. 703 (1925) which is no "public policy" case at all; jurisdiction over an equitable right of action was denied because the plaintiff's claim was considered "too tenuous."

36. Thus in Fox v. Postal Telegraph Co., 138 Wis. 648, 120 N. W. 399 (1909), a provision in the contract, limiting the defendant's liability for orderly delivery of the telegram, was held void as violating the public policy of Wisconsin. No Wisconsin contact was mentioned in the decision, but doubtless the defendant had branch establishments in Wisconsin. The ruling, therefore, greatly affected Wisconsin interests. An absolute use of the public policy rule, however, seems to exist in the following two cases. In Folsom v. Continental Adjustment Corp., 48 Ga. App. 435, 172 S. E. 833 (1933), the court applied the Georgia usury statute despite the absence of Georgia contacts to a small loan, characterizing the interest rate agreed upon as "unreasonable and unconscionable." This is, 
While with respect to reliance on contacts, Anglo-American cases, on the whole, are in accord with continental decisions, some divergent features of American doctrine must be mentioned. One feature has been elaborated in Bradford Electric Light Company, Incorporated a. Clapper. ${ }^{37}$ There the defendant company had employed the plaintiff's husband as a lineman in New Hampshire where he was killed in an accident during the course of his employment. Employer and employee were both Vermont citizens. Against the plaintiff's suit, brought in a New Hampshire court for workmen's compensation, the company set up a defense that the action was barred by the Vermont Workmen's Compensation Act. The plaintiff insisted that this provision of the Vermont statute was contrary to the public policy of New Hampshire (and hence inapplicable). The Supreme Court of the United States, however, refused to accept this replication:

"A state may, on occasion, decline to enforce a cause of action. In doing so, it merely denies a remedy, leaving unimpaired the plaintiff's substantive right, so that he is free to enforce it elsewhere. But to refuse to give effect to a substantive defense under the applicable law of another state, as under the circumstances here presented, subjects the defendant to irremediable liability. This may not be done. ..." 38

The result is that the court is divested of its power to discard a foreign law for reasons of public policy, as soon as the foreign law is invoked by the defendant.

Common carriers sued in American courts for damages have repeatedly advanced as a defense exculpating clauses, valid under their own law; and have been held liable because the foreign rule on such clauses ran counter to American public policy. ${ }^{30}$ According to Mr. Justice Brandeis' theory, the carriers should have won because they pleaded the foreign law in the capacity of defendants. But such a result would be puzzling. True, Mr. Justice Brandeis had before him an interstate situation, a fact which technically may be used to narrow the effect of the case as

nevertheless, not the general attitude of American courts in usury cases. See Nussexu:s, MONEY IN THE LAW (1939) 245. In Oscanyan v. Winchester Arms Cu., 103 U. S. 261 (1880), the Court refused to consider a Turkish law according to which the plaintiff, a representative of the Turkish government, was allegedly permitted to agree with the dsfendant company on a commission for the sales of arms to the Government. That cause of action was deemed "so repugnant to all our notions of right and morality that it can have no countenance in the courts of the United States."

37. 286 U. S. 145 (1932).

38. Id. at 160 .

39. See cases cited infra notes 43 and 44 , and Carstens Packing Co. v. Southern Pac Co., 58 Wash. 239, 108 Pac. 613 (1910). 
precedent, but logically the argument carries over to international situations. The argument does not stand analysis. Is it justifiable to award the defendant a more favorable position in matters of public policy or to deprive the court in any stage of the judicial process of the power to protect the interest of its state by the use of that concept? Mr. Justice Brandeis doubtless felt uneasy in giving the law of one American state precedence over the law of a sister state, and this sentiment led to indecision which, in reality, favored the defendant. However, the federal court stands in the shoes of a state court, and has to look exclusively to the law of that state, notwithstanding the fact that courts of another state may decide differently. This is but an aspect of the broader phenomenon that a party liable under the law of state $A$ is sometimes not liable under the law of state $B$. A corrective, if any, could only be secured by the evolution of uniformity of the law concerning jurisdiction.

Fortunately, the doctrine of the Clapper case, though not yet overruled, is isolated ${ }^{40}$ and unlikely to be followed in the future. It is true that Section 612 of the Restatement mentions public policy only in connection with "actions," 41 but the omission of defenses seems to be an oversight due to the unfortunate "vested right" theory which was adopted by the fathers of the Restatement. The official comment does not suggest that public policy should not operate where foreign law is relied upon by the defendant. In fact, the contrary was held by the Supreme Court in an earlier case, ${ }^{42}$ and in a number of cases by lower federal ${ }^{43}$ and by state courts. $^{44}$ In the Bradford case itself, Mr. Justice Stone, in a tense concurring opinion, implicitly rejected Mr. Justice Brandeis' theory. Actually, no vestige of anything resembling that theory is found in the extensive continental and English literature on public policy.

Another peculiarity of the American doctrine of public policy is perhaps related to the philosophy behind the Clapper case, i.e., the legal effects of the use of the public policy rule. In an outstanding opinion,

40. Apart, perhaps, from Home Insurance Co. v. Dick, 281 U. S. 397 (1930), opinion written by Mr. Justice Brandeis, where the seeds of his theory may already be found.

41. "No action can be maintained upon a cause of action created in another state the enforcement of which is contrary to the strong public policy of the forum." ResTATEAENT, CONFLICT OF LAWS (1934) §612.

42. The Kensington, 183 U. S. 263 (1902).

43. Northern P. R. R. v. Kempton, 138 Fed. 992 (C. C. A. 9th, 1905); Oceanic Steam Navigation Co. v. Corcoran, 9 F. (2d) 724 (C. C. A. 2d, 1925); The Fri, 154 Fed. 333 (C. C. A. 2d, 1907).

44. Carstens Packing Co. v. Southern Pac. Co., 58 Wash. 239, 108 Pac. 613 (1910); Meacham v. Jamestown R. R., 211 N. Y. 346, 105 N. E. 653 (1914); Frenkel \& Co. v. L'Urbaine Fire Ins. Co., 251 N. Y. 243, 167 N. E. 430 (1929) ; Petrogradsky Mejdunarodny Kommerchesky Bank v. National City Bank, 253 N. Y. 23, 170 N. E. 479 (1930) ; Vladikavkasky Ry. r. New York Trust Co., 263 N. Y. 369, 189 N. E. 456 (1934). 
Loucks v. Standard Oil Company, ${ }^{45}$ Judge Cardozo took the view that the courts must "decline jurisdiction" and "close the door to the plaintiff" when his foreign right is denied for reasons of public policy; but if the claim is allowed, then jurisdiction must be assumed. Apparently these formulas purport to make it clear that the losing plaintiff may try his luck in any foreign court unhampered by the judgment rendered. Still it is questionable whether this is the proper way by which to achieve a desirable end. Suppose the defendant is held liable, because his defense is rejected under a public policy of the forum. The judgment then is undoubtedly on the merits. It cannot be otherwise, where the plaintiff's claim is rejected on the same ground. In fact, where the foreign right claimed by the plaintiff is not recognized in the forum, there is no right at all left for judicial disposition. Hence, the forum has simply to dismiss the claim, just as in the case of any other action involving a cause of action not recognized by law. The relation of Judge Cardozo's theory to that of the Clapper case consists in the court's sentiment that the use of the public policy argument must not have a definitive effect - in the Clapper case, against the defendant; in the Loucks case, against the plaintiff.

Certainly the plaintiff should not be prevented from bringing suit in another jurisdiction. On any theory, the judgment rendered says no more than that the vindicated claim was not recognized because it violated the forum's public policy. Hence recognition of this judgment under the full faith and credit clause should not stand in the way of a fresh action by the same plaintiff in another jurisdiction. ${ }^{40}$ In such a situation, the courts of the sister state, the law of which was denied recognition, should certainly be held empowered to turn the public policy argument against the judgment. As a result, no need exists for a jurisdictional theory. Still there is a certain inclination of English and American courts, explicable perhaps by historical reminiscences, ${ }^{47}$ to couch choice-of-law problems in jurisdictional terms. ${ }^{48}$ While here and there this language may simply be considered as indeliberate and inaccurate, such interpretation does not seem permissible in view of Judge Cardozo's explicit and recurrent phraseology. Obviously, a definite jurisdictional view is

45. 224 N. Y. 99,120 N. E. 198 (1918).

46. See the opinion of the Reichsgericht, infra note 50.

47. See 5 Holdsworte, A History of Exglise Law (1924) 117 ef scq., 140 ef scq., and the valuable article of SACK, Conflicts of Laus in the History of the Englis/s Law in 3 Law: A Century of Progress (1937) 342.

48. For instance, Chambers v. Baltimore \& Ohio R. R., 207 U. S. 142 (1907), and Sweeney v. Hunter, $145 \mathrm{~Pa}$. 363, 22 Atl. 653 (1891) are in the writer's opinion concerned with questions of substantive law, despite their jurisdictional phrascologs: 
behind it. But this view has not been generally accepted in this country. ${ }^{40}$ Again, on the continent there is no vestige of it..$^{50}$

In the Loucks case, the jurisdictional theory did not affect the outcome of the case, the defendant being held liable for other perfectly sound reasons. It did not even prejudice the persuasive flow and consistency of Judge Cardozo's opinion. The confusing effect of the underlying theory appears, however, in Mertz $v$. Mertz, ${ }^{51}$ where a New York wife sued her husband for damages because of injuries suffered in Connecticut. The Connecticut law, unlike the New York law, allows such suits between husbands and wives. Upon appeal, Judge Lehman demonstrated at length, citing the Loucks case, that the Connecticut rule was against public policy. To bolster this argument, theories of jurisdiction and remedies were employed. As a consequence, the complaint was dismissed on the ground that New York, "while recognizing the wrong, denies a remedy by attaching to the person of the spouse a disability that cannot

49. The language of the courts is ordinarily indifferent. The frectuent expression that the controversy turns on the "enforcenent of an obligation" (of the debtor) speaks rather in favor of a substantive law theory of public policy. See, c.g., Walsh $v$. New York \& N. E. Ry., 160 Mass. 571, 36 N. E. 584 (1893) ; comment to $\$ 612$ of ResTATEMENT [p. 1034 supra], although far from being clear, seems to support the same theory. However, Watson v. Murray, 23 N. J. Eq. 257 (1872), denying, for reasons of public policy, enforcement of a foreign lottery transaction, already employs jurisclictional language.

In suits between non-residents, assumption of jurisdiction is sonetimes made dependent on the fact that the cause of action is not contrary to the public policy of the fortum. Eingartner v. Illinois Steel Co., 94 Wis. 70, 68 N. W. 664 (1896); Hudson v. von Hamm, 38 Cal. App. 323, 259 Pac. 374 (1927) ; Loranger v. Nadeau, 215 Cal. 362, 10 P. (2d) 63 (1932). Here public policy appears within a veritable jurisdictional setting. But one may doubt whether in fact more is involved than exercise of the discretion conferred upon the courts in such situations.

50. The problem underlying the American cases was touched upon by the Reichsgericht, 29 Entscheidungen in Zivilsachen 90 (June 9, 1892). In the port of Reval (Esthonia), an English ship through the negligence of her obligatory Reval pilot had injured a Dutch ship. A suit for damages brought against sureties of the English shipowner was dismissed by the Reichsgericht on the ground that according to German public policy a shipowner is not responsible for acts done by an obligatory pilot. The case is one of the not too numerous German cases which unduly expand public policy inasmuch as the relativity principle was entirely overlooked by the court. Perhaps feeling the weakness of the position taken, the court remarked: "Dismissal by the German court [italics the court's] means but that the plaintiff's claim cannot be enforced within Germany. This judgment does not claim to dispose of the plaintiff's right absolutely. ["schlechlhin"]. The plaintiff is not prevented from prosecuting his right in the court of another state whose laws who do not preclude his claim . . . even should those courts ordinarily enforce German judgments." While this statement consoling the plaintiff was unnecessary, it was accurate in describing the lack of any extraterritorial effect of the judgment. But it did not occur to the Reichsgericht that the controversy turned on the point of jurisdiction.

51. 271 N. Y. 466,3 N. E. (2d) 597 (1936). 
be removed by the law of another state. The law of the forum determines the jurisdiction of the courts, the capacity to sue or to be sued, the remedies which are available to suitors and the procedure of the courts." 52 Of course, the elaborate discussion of public policy was out of place, but here too, the weakness in reasoning did not affect the soundness of the result which was justifiable according to the procedural theory. ${ }^{53}$

\section{The Reserve of Exglish and Aarericix Courts in the Use of Public Policy}

The most striking feature of Anglo-American law with regard to public policy is easier to describe than to define in legal propositions. This feature is the courts' dislike of public policy - the uneasiness exhibited by them where circumstances impose consideration of the public policy rule. True, antipathy to public policy is by no means confined to common law countries. To the continental systematicians of international private law, it is the "Cerberus" lying at the threshold of the international private law, ${ }^{54}$ an enigmatic ${ }^{55}$ monster which shows no desire of being analyzed, and which defies the concerted attacks of professors, daring thesis writers ${ }^{56}$ and treaty makers. ${ }^{57}$ Still, continental courts differ from juristic writers in this respect. Much as they are subject to the

52. Mertz v. Mertz, 271 N. Y. 466, 473, 3 N. E. (2d) 597, 600 (1936).

53. The objections by Goonsich, Cosfuict of Laws (2d ed. 1938) $231, n$. 45 result from his general aversion against the use of the public policy argument which he arparently considers the basis of the opinion. This interpretation of the opinion by a leading expert in the field brings home the inadequacy of the language used. Poling v. Poling, 116 W. Va. 187, 179 S. E. 604 (1935) is an analogous case decided on a purely public policy basis.

The question of theoretical accuracy becomes more important with respect to textbrols. A vestige of the jurisdictional conception may be found in Parmele's annotations to Wharton's Conflict of Laws (3d ed. 1905) 1118 et seq. The more recent Ameriean textbooks seem definitely to be influenced by Justice Cardozo's view. So excellent a guide as Stumberg's Conflict of Laces, presents the general discussion of public policy and special discussions as to contracts, torts and foreign judgments in the chapter on Procedure [(1937) 150 et seq.] Public policy is there affiliated, or rather confused, with purely procedural matters such as forum non conveniens, litigations between non-residents (sce note 49 sitpra) and the hesitancy of the courts to assume jurisdiction in matters interiering with the internal management of foreign corporations. No such organization is used by English and continental authors.

54. See Lewald, supra note 23 , at 152.

55. 1 Bartin, Principes de Droit Internatrox.al Prive (1930) 210.

56. For comprehensive bibliographies on continental public policy doetrine, see Knapp, La Notion de l'ordre public dans les Confits de Lois (Thesis, Neufchatel, 1933) ; Lienhard, La Role et la Valeur de l'ordre Public (Thesis, Dijon, 1934); Cf. also Krusren, Arbeitsvertrag und Ordre Public (1933). The disproportion between the amount of writings on the subject and the value of the results attained is frightening indeed.

57. See Lewald, supra note 23; Knapp, supra note 56, at 132 at seq. 
influence of legal learning in the conflicts field, continental judges have never hesitated to employ the public policy weapon. If in this respect their course is open to objection, it can only be for an exaggerated use of that weapon. ${ }^{58}$ English and American judicial opinions, however, in uncommon union with continental systematicians, are full of regrets and excuses for public policy. Since 1824, Judge Burrough's "unruly horse" has become the symbol of that mental attitude: "once you get astride of it, you never know where it will carry you." "so Quotations of this remark $^{60}$ and other judicial warnings ${ }^{61}$ on public policy are frequently made by English and American courts. Quite preponderantly the cases in question are concerned with the contract use of the public policy concept, the courts in question refraining from that use for acceptable reasons.

Since the World War, however, the public policy problem has entered a new phase. Revolutionary and destructive legislative inroads into national and international economics have shifted the focus of public policy to the conflicts area. Here, perseverance of the old tradition, under changed conditions, has led to highly unsatisfactory rulings.

In Dougherty v. Equitable Life Assurance Society, ${ }^{\text {a2 }}$ the New York Court of Appeals was concerned with ruble policies issued before 1917 by the defendant's Petrograd branch to persons who, with one or two exceptions, ${ }^{63}$ were Russian citizens. In 1919 , when many of the insured had ceased to be subjects or residents of Russia, the policies were cancelled by a decree of the Soviet Government. ${ }^{64}$ The suits brought by

58. A number of earlier German, French and Italian cases is listed by 1 KAuN, Abhandlungen zum Intersationalen Privatrecht (1928) 247, n. 132. For further and more recent German instances see Nussbaum, Deutsches Internationales Pr1vatrecht (1932) 66, n. 2, and the case supra note 50. Regarding the attitude of French courts, cf. Wolff, Internationales Privatrecht (1933) 41. A striking Norwegian instance is referred to in Nussbaum, MoNEY in the Law (1939) 396, 11. 76.

59. Richardson v. Mellish, 2 Bing. 229, 252, 130 Eng. Rep. 294, 303 (1824).

60. In re Kelcey, [1899] 2 Ch. 530, 534; In re Smith, [1914] 1 Ch. 937, 946; Hugston v. Bell, 185 Ind. 536, 544, 112 N. E. 883,886 (1916); Veytia v. Alvares, 30 Wis. 316, 247 Pac. 117 (1926); and other cases.

61. See Fendor v. St. John Mildway, [1938] A. C. 1, 10, 11 (1937) and cases listed there; McQuade v. Stoneham, 263 N. Y. 323, 329, 189 N. E. 234, 236 (1934), (1935) 44 YALE L. J. 873. It is remarkable that in Egerton v. Bronslaw, 1853/4 H.C.L. 1 (1853) the contract-use of public policy in so far as it exceeded the "policy of well established law" was maintained only with great difficulty.

62. 266 N. Y. 71, 193 N. E. 897 (1934).

63. One exception is referred to by Judge Lehman, concurring, at $104,193 \mathrm{~N}$. E. at 909. The majority opinion, at $78,193 \mathrm{~N}$. E. at 898 , mentions that "the policies were all bought . . . by Russian citizens," but at 83, 193 N. E. at 900 . speaks of "Russia where all the insured were, with one or two exceptions." Although the latter remark seems to envisage the year 1918, it should probably be related to the time of contracting.

64. True, the company's Russian assets had been confiscated by the Bolshevist Government, but they were, or would have become, worthless anyhow due to the depreciation 
the insured for payment were dismissed by the court, partly on the ground that the ruble contracted for had evaporated. But the majority of the court based the dismissal also on the view that the policies had been validly cancelled by Soviet legislation. The court took the position that there were not sufficient contacts for the use of the public policy rule. However, the insurance company was American; a fact doubly material, because the independence of the company amidst disquieting Russian conditions, together with the high reputation and the large resources of the Equitable, offered strong incentives to prospective Russian policy holders. Of course, cancellation of policies without compensation meant a profit to the American insurance company, but securing profits of that type obviously is no reason for withholding the public policy argument, and nothing in the judgment suggests that the court was influenced by such considerations.

Further contacts were present, such as the fact that a few of the insured had not been Russian citizens at the time of contracting ${ }^{65}$ and more of them were not residents of Russia at the time of the hearings. The possibility that American citizens or residents were among the insured must be assumed in the absence of statements to the contrary, since the judgments must be understood to cover all claims presented. Thus, the contacts were clearly sufficient to warrant resort to public policy.

In addition to the alleged lack of contacts, the majority's opinion offers another argument for not using public policy. The People's Commissariat of Justice had decreed, with the force of law, that the cancelling ordinance "had no application" to contracts of life insurance made by Russian subjects with companies having assets in the United States. The objective of the decree was manifest: the Soviet Government wanted to preserve, as a precious asset for subsequent confiscation, insurance claims in dollars or rubles enuring to Russian citizens and possibly collectible in the United States, then the gold standard country par excellence. But the court, using its own judgment, read into the Commissariat's decree a limitation to the effect that only contracts made in New York or to be performed here according to New York law were envisaged by the exemption; the reason being that "naturally" such contracts "could not" be affected by the cancellation. This construction made the Soviet decree an innocuous essay in American private international law, with the result that cancellation without compensation was widened by the American

of the ruble. To this extent the company was more than protected by the simultansous depreciation of the ruble policies. A part of the premiums paid on the Russian policies had probably been transferred to this country. The court does not discuss this point nor do the reasons given by the majority refer to the confiscation of the company's Russian assets.

65. See note 64 supra. 
court. But at least the cancelling ordinances were saved from the inroads of public policy.

In the Dougherty case, dismissal of the complaints was warranted because of the annihilation of the ruble. There are, however, cases the disposition of which entirely depend on the public policy argument. They exhibit even more the trend appearing in the Dougherty case, namely, an endeavor to eliminate the foreign law indirectly by utterly tenuous arguments rather than by frank resort to public policy. ${ }^{68}$ Restrictive interpretation of the foreign law, by an ipse dixit of the court contrary to the true intent of the foreign legislature, is a familiar device. Thus in First Russian Insurance Company v. London \& Lancashire Insurance Company, ${ }^{67}$ Romer, J., exempted the London Branch of the Russian company from the effects of the Russian nationalization decrees, negativing, with no support in the text of the decrees, the statements of the expert on Russian law whose testimony was not challenged.

Exactly the same thing happened in Moscow Fire Insurance Company v. Bank of New York \& Trust Company. ${ }^{68}$ The United States, as assignee of the Soviet Government, claimed, by way of intervention, the proceeds of the liquidation of the company's New York branch, the proceeds being held by the defendant. The court denied the Government's claim and subjected the liquidation of the New York branch entirely to New York law. The court's assertion in this case that the Soviet Government had itself territorially limited the legal effects of its nationalization decree ${ }^{30}$ contradicted not only the expert testimony but the fact that the Soviet Government, by its assignment, had ascribed to its own decree a different meaning. Moreover, despite the court's contention, dissolution of a juristic person is necessarily intended to affect, though indirectly, all of its assets wherever situated. ${ }^{70}$ Repercussions of the dissolution in the New

66. The decision of the Reichsgericht of Nov. 14, 1929, in the Viennese loan case, 126 Entscheidungen in Zivilsachen 196, discussed in Nussbaum, MONEY IN THE LAw (1939) 383, offers a continental instance. The lower appellate court had in a neat and cogent opinion reached the sound result by an explicit use of the public policy argument. The over-artificial dialectics of the Reichsgericht reasoning in obscure conflicts terms met with unanimous disapproval of the commentators: 29 SoNTAG, BaNkarcirtv (1930) 360; Neumeyer, INTERnationales VerwaltungsRecht (1930) III(2) (3) 323, n. 17; Heinrici, (1930) JURIstische Wochenschrift 1855; Reichel, 1930 id. at 2209; Kössler, $1931 \mathrm{id}$. at 148 . The court apparently was afraid to touch upon Austrian sensibilities and, perhaps, to create, by the use of the public policy argument, a precedent which might be turned by foreign courts against similar German enactments. NUSSBaUM, MONEY IN THE LAw (1939) 357, n. 4. Kössler, for example, speaks of the court's "diplomatic" reasoning.

67. [1928] Ch. D. 922.

68. 280 N. Y. 286,20 N. E. (2d) 758 (1939), 49 YaLe L. J. 324.

69. See the referee's statements as quoted. Moscow Fire Ins. Co. v. Bank of New York \& Trust Co., 280 N. Y. 286, 306, 20 N. E. (2d) 758, 765 (1939).

70. The counterarguments advanced by Rippey, $J$. dissenting, appear convincing in this respect. Id. at $314,20 \mathrm{~N}$. E. (2d) at 769. 
York area certainly may be curtailed here, but only by means of the public policy concept ${ }^{71}$ or by specific legislation.

Although not exactly in point, the English case, Sedgirick, Collins and Company v. Russia Insurance Company of Petrograd, ${ }^{72}$ is relevant here. Long after the nationalization of the Russian company, a writ had been served on its former agent in London, on its behalf. The validity of the service was questioned. Said Bankes, L. J., "Any civilized nation whose national takes advantage of our municipal law in order to secure a business footing in this country, will observe and recognize the conditions upon which the national takes that advantage." 33 From this premise Lord Bankes drew the conclusion, which he considered as not subject to doubt, that the Soviet Government would recognize the validity of the service and that this event might be anticipated. He could validly have drawn the conclusion that he would not consider the Soviet Government as civilized in case it would deny the recognition. This statement, however, would not have carried much weight, as no less an authority than Lord Scrutton, dissenting, gainsaid Lord Bankes' theory on the assumed obligation of the Soviet. Nor was there the slightest factual foundation for Lord Bankes' conclusion. Essentially the case amounts to a reductio ad absurdum of the interpretative technique used in the decisions previously discussed. ${ }^{74}$

While the number of cases which originated in the Russian Revolution is gradually melting away, litigation arising from foreign impairment of contract obligation through exchange-control, abrogation of gold clauses, compulsory reduction of interest rates and similar measures are coming more and more to the fore. Particularly injurious in the international field is foreign exchange-control legislation which makes transfer of money over the country's frontiers dependent upon government license and which may result, as it did in Germany, in a sweeping prohibition

71. See note 104 infra.

72. [1926] K. B. 1.

73. Id. at 8 .

74. The use of that technigue is not limited to the decisions mentiunte. In a manner not so gross it appears, for instance, in Washington Alaska Bank y. Dester Horton Xat. Bank, 263 Fed. 204 (C. C. A. 9th, 1920). The Seattle bank, a creditor of the bankrupt Washington-Alaska Bank, which had been incorporated in Nevada, was denied rayment by the Nevada receivers because under the Nevada Banking Lav "depositors" and "holders of exchange" enjoyed a preference in the funds of the debtor company. The court sitting as an Alaskan court, held the Nevada statute inapplicable to the creditor's rights flowing from an Alaskan transaction, a decision certainly justifiable from the vieupsint of Alaskan public policy. However, the majority of the court based the decision upon an unconvincing interpretation of the Nevada law into which the majority read a territorial limitation, not deductible from the text of the preference provision. Obviously the adjudication must have been the same if the Nevada law did not contain such a limitation.

In De Brimont v. Penniman, 7 Fed. Cas. 309 (C. C. S. D. N. Y. 1873), the court found in the provisions of the French Civil Code on alimony, by way of mere speculation, an illdefined "local character" not indicated in the text of the Code. In this case, also, the public policy argument was cumulatively used, although not in so many words. 
of transfers necessary for the payments of debts. Courts have been almost unanimous in disregarding foreign exchange-control legislation. Outsicle the United States, courts have relied on public policy and related formulas. ${ }^{75}$ In this country they have, in the great majority of cases, availed themselves of the accidental fact that under the contract the foreign debtor had to make payment in America so as to subject the contract to American law. ${ }^{76}$ This criterion is unsatisfactory. In olden times when transportation of money was quite a venture, the place of payment was actually an important factor in shaping the debtor's obligation. Under modern banking practice, the place of payment carries little weight, except in outmoded legal theory. ${ }^{77}$

Moreover, even under the place-of-payment theory, the question remains whether the German or other foreign debtor is exonerated because of impossibility of performance, brought about by foreign exchange-control. In a well-reasoned opinion, a New York federal district court rejected the impossibility defense on the theory that the debtor might have been able to make payment out of funds held here. ${ }^{78}$ The court had not been informed, it seems, that exchange-control also forbids debtors to make payments from funds held abroad; such funds being subject to repatriation as soon as conditions permit. The rule under which impossibility due to foreign law is not a good defense ${ }^{70}$ offers the creditor a stronger protection, but is predicated upon the applicability of American or English law. Still this prerequisite may be absent. The problem before us appears there in its clearest form.

In two cases, ${ }^{80}$ German debtors had agreed to make payment in Holland. Their impossibility defenses were rejected by a New York court, mainly

75. See Nussbaum, Money in the Law (1939) 488. Also Hooge Raad of the Netherlands, May 26, 1939, (1939) NederLand 'sche Jurisprudentie 1386, (1939) IsSTITUT JURIDIQUe INTERnational Bull. 90, regarding the loan of the Osram Company; Appellate Court of Colmar, March 11, 1938, (1938) Nouvelle Revue de Droit INTERNATIONAL PRIVÉ 699.

76. Central Hanover Bank \& Trust Co. v. Siemens \& Halske Aktiengesellschaft, 15 F. Supp. 927 (S. D. N. Y. 1936), aff'd, 84 F. (2d) 993 (C. C. A. 2d, 1936), cert. denicd, 299 U. S. 585 (1936) ; Perry v. North German Lloyd, 150 Misc. 73, 268 N. Y. Supp. 525 (Mun. Ct. 1934); Glynn v. United States Steel Works, 160 Misc. 405, 289 N. Y. Supp. 1037 (Sup. Ct. 1935) ; Sheppard v. Hamburg-Amerikanische-Paketfahrt Actiengesellschaft, N. Y. L. J., Mar. 14, 1934, p. 1232, aff'd, N. Y. L. J., Apr. 6, 1934, p. 1653 (App. Term), leave to appeal denied, see Glynn v. United States Steel Works, supra, at 409; Deutsch v. Gutehoffnungshütte, 168 Misc. 872, 6 N. Y. S. (2d) 319 (Sup. Ct. 1938); Barnes v. United States Steel Works Corp., 11 N. Y. S. (2d) 161 (Sup. Ct. 1939); Kleinwort, Sons \& Co. v. Ungarische Baumwolle Industrie, T. L. R. 814 (C. A. 1939).

77. See Nussbaum, Money in tee Law (1939) 225.

78. Central Hanover Bank \& Trust Co. v. Siemens \& Halske Aktiengesellschaft, stipra note 76.

79. See note 27 supra.

80. Lann v. United States Steel Works Corp., 166 Misc. 465, 161 N. Y. (2d) 951 (Sup. Ct. 1938) ; Pan-American Securities Corp. v. Friedrich Krupp Aktiengesellschaft, 169 Misc. 445, 6 N. Y. S. (2d) 993 (Sup. Ct. 1938). 
on the ground that, under Dutch law, German exchange-control legislation did not furnish a valid excuse for the debtor's default. This Dutch rule, however, is merely the expression of Dutch public policy, a fact which was perhaps not explained to the court. From the viewpoint of an American court, there is no reason to prefer Dutch public policy over German public policy. There is only one kind of public policy which an American court must heed; namely, American public policy, which may require the court to safeguard the interests of American residents.

The problem of inapplicability of American law was also presented in Goodman v. Deutsch Atlantische Telegraphen Gesellschaft. ${ }^{81}$ Suit had been brought on bonds which were issued in this country by the defendant, with a New York company as trustee. The trust deed expressly stated that the obligations of the defendant were "covered" by the law of Germany. The defendant, alleging German exchange-control, refused payment. The court overruled the defense, but at the same time vigorously opposed the public policy argument. By the use of that argument, the court was unwilling to "assume a pharisaical attitude and thank Providence that we are not like other people." The opinion also passed strictures on "American investors who seek high percentage rates on foreign bonds" (the bonds in question bore seven percent per annum). The inevitable conclusion of these premises seems to be dismissal of the complaint. But no, the court found that the contract, though explicitly "corered" by German law, was implicitly "governed" by American law. For this reason. German exchange-control did not come into play. Hence, what was evidently necessary for reasons of public policy was attained in a round-about fashion which was by no means preferable to a frank reliance on public policy.

There is only one case in which an American court has yielded to German exchange-control legislation. a case in which the suit of an Austrian emigré for payment of her account with a Prague bank was dismissed. The absence of an American place of payment proved detrimental to the plaintiff; and the court itself expressed uneasiness over its disposition of the case. ${ }^{82}$

British and French Trust Corporation v. Newi Brunswick Railaray Company ${ }^{83}$ is a conspicuous case concerned with foreign gold clause abrogation. In 1884 the defendant had issued bonds in terms of " $£ 100$ gold coin of Great Britain of the present weight and fineness," payable, at the option of the holder, in London or in New Brunswick. After Canada, in 1937, had abrogated gold clauses, ${ }^{84}$ the English Court of Appeal, as

81. 166 Misc. 509, 2 N. Y. S. (2d) 80 (Sup. Ct. 193S).

82. Werfel v. Böhmische Escomptebank, N. J. L. I., July 20, 1939, p. 161.

83. [1938] 4 All E. L. R. 747 .

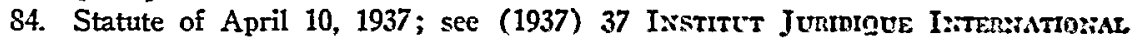
BULI. 109. 
well as the House of Lords, on a suit brought by bondholders, held the New Brunswick company liable for the full gold amount as promised. Non-recognition of foreign gold clause abrogation, for reasons of public policy, has repeatedly been enunciated by the highest courts. ${ }^{85}$ Thus in the New Brunswick case, English contacts warranting the use of the public policy rule were amply present, particularly in the alternative English place of payment, the English currency and the flotation of the loan in England. But the courts shunned this argument. The Court of Appeal ${ }^{86}$ advanced a novel theory according to which the "measure" (as distinguished from the "manner") of the debtor's performance is controlled by the law of the place of performance. This theory has been criticized elsewhere ${ }^{87}$ and was abandoned by the House of Lords. The highest English court, however, in a most striking way, used the device discussed above to read into the Canadian statute limitations excluding its application to the case at bar, contrary to the manifest intention of the Canadian legislature.

The Canadian Act was shaped after the American Joint Resolution of June $5,1935 .{ }^{88}$ While the American law abrogates only gold dollar clauses, at least in its text, ${ }^{80}$ Section 4 of the Canadian act goes further:

"In the case of any gold clause obligation governed by the law of Canada payment in Canada or elsewhere, in money other than money of Canada tender of the nominal or face amount of the obligation in currency which is legal tender for the payment of debts in the country in the money of which the obligation is payable shall be a legal tender and the debtor shall, on making payment in accordance with such a tender, be entitled to a discharge of the obligation."

The $£ 100$ bond of the New Brunswick Railway Company clearly came under this provision. It constituted a "gold clause obligation;" it was, as admitted by the court, "governed by the law of Canada;" it was payable, not in Canada, but "elsewhere" (in London) "in money other than money of Canada." Consequently "tender of the nominal or face amount," i.e., tender of $£ 100$, in English currency ("currency which is legal tender for the payment of debts in the country in the money of which the obligation is payable") was "a legal tender," and the company, on making payment in accordance with such a tender, was "entitled to a discharge of the obligation," notwithstanding the fact that the latter ran in terms of $£ 100$ gold.

85. Nussbaum, Money in the Law (1939) 392-394 (Dutch, German and Swiss decisions). 516.

86. British \& French Trust Corp. v. New Brunswick Ry. Co., [1937] 4 All E. L. R.

87. Drunsfield v. British Insulated Cables, Ltd., [1937] 4 All E. L. R. 382.

88. 48 Stat. 112, 31 U. S. C. $\$ 463$ (1933).

89. See, however, Guaranty Trust Co., Trustee, v. Henwood, 307 U. S. 247 (1939). 
But the Iords looked upon the situation in a different way. Lord Maugham, with whom the other Lords in substance agreed, pointed out that "questions that arise as to the validity or form of a tender, or the advantage of making one in a particular form, are questions of procedure for the lex fori." Under English law a mere tender of money; so the argument runs, would not discharge the debt; a tender conforming to the rules of court would only stop the running of interest and shift the burden of cost to the debtor. "I cannot think that the legislature of Canada was attempting to alter the course of procedure in any country except Canada." 90 The baffling result is that Section 4 must be confined to actions brought in Canada.

Yet there is no foundation for the assumption that Section 4 is procedural in nature. Tendering money may be part of a judicial procedure; in itself it is not. ${ }^{91}$ In the case of Section 4 there is not the slightest hint of a procedural objective. The words of the section italicized in the following - "tender of the nominal or face amount of the obligation . . . shall be a legal tender and the debtor . . . shall be entitled to a discharge of the obligation" - were not heeded by the Lords in their purely literal analysis. Those words make it clear that nothing short of a curtailment of creditors' rights was intended by the Canadian legislature. The creditor was to be divested of the right to enforce more than the nominal amount of the obligation. The whole act is a measure of substantive law just as is the American Joint Resolution. The near possibility of such an unstrained interpretation of the Act was not considered by the courts. We refrain from elaborating other objections to the theory of the court. ${ }^{92}$ In the proceedings before the Court of Appeal, nobody, not even plaintiff's counsel, had hit on that theory nor has it been advanced in foreign litigation over the Canadian Act. ${ }^{\text {פ3 }}$

Canada struck back. In 1939 she enacted with retroactive force a new Gold Clause Act making impossible any further misinterpretation of the type which had occurred. At the same time the enforcement of foreign judgments, not in harmony with the new Act, was forbidden. ${ }^{2 s}$

90. British and French Trust Corp. v. New Brunswick Ry., [1938] 4 All E. L. R. $747,757$.

91. See Nussbaudr, op. cit. supra note 85 , at 37.

92. The court's construction of the Canadian Act implies that foreign (English) money would have to be paid into the Canadian court. By a strange coincidence, such a proceeding was held unlawrul, and duly so by the Privy Council in the same volume in which the decision of the House of Lords was first reported. Pyrmont $v$ Schott, [1938] 4 All E. L. R. 713, 718.

93. Judgment of the Hooge Raad of the Netherlands, April 28, 1939, (1939) NEdzsLAND 'SCEE JURISPRUDENTIE 1377, regarding the Canadian gold dollar loan of the Miessageries Maritimes.

94. Gold Clauses Act, 1939. See (1939) 41 Institut Jurmbou Imtenintio:ial BULI. 84. 


\section{Appraisal of the Anglo-American Tradition Regarding Public Policy}

How is the hesitation of the English and American courts in the use of the public policy rule explainable?

In some cases, special reasons account for the attitude of the court. In the New Brunswick case, the court probably felt the pressure of the decision in Rex $v$. International Trustee for the Protection of Foreign Bondholders, ${ }^{95}$ where the House of Lords had taken off the shoulders of the English Government and taxpayers the formidable burden of the gold clause of the Morgan war loan. Should public policy be allowed to recognize foreign gold clause abrogation in the interest of domestic debtors, but to deny recognition where recognition would principally prejudice domestic creditors? Perhaps. It will be seen that the problem is not an ethical one. It would, however, have been an act of enlightened judicial statesmanship to pay for the advantages obtained from foreign gold clause abrogation, by squarely accepting its disadvantages.

Regarding the Moscow Insurance case, it has been correctly pointed out in an able comment ${ }^{96}$ that the court was precluded from direct reliance on public policy by United States $v$. Belmont, ${ }^{97}$ where the state courts were sternly admonished for interfering with international agreements of the Federal Government, even in cases involving the public policy of a state. Besides, it would be a strange thing, indeed, for an American court to turn, for reasons of "public policy," against the Government of the United States.

But these searches into the special motives of individual cases do not tell the whole story. The hesitant attitude of the courts towards public policy is a general phenomenon which demands a more comprehensive explanation. Dislike of presumptuousness, of a "pharisaical attitude" is suggested as a rationale in the Goodman case, and similar views have occasionally appeared elsewhere. ${ }^{98}$ But certainly not much importance can be attributed to this motive. All things considered, the numerous highest courts of civil and common law countries which have availed themselves of the public policy argument cannot possibly be reprehended as hypocritical. The remark in the Goodman cases rests on misapprehension. Conflicts use of the public policy concept means merely that in the case of strongly conflicting policies, a court must follow the local policy rather than the policy of a foreign state. This limitation upon the recognition of foreign law may be considered as somewhat political, but in no event does it involve an ethical stricture on the foreign law.

95. [1937] A. C. 501.

96. (1939) 48 Yale L. J. 324.

97. 301 U. S. 324 (1939).

98. See, e.g., Beach, Uniform Interstate Enforcement of Vested Rights (1918) 27 YALE L. J. 656; Goodrich, Foreign Facts and Local Fancies (1938) 25 VA. L. REv. 26. 
A foreign law may run counter to the public policy of the forum, albeit the forum possesses a similar law. Thus the Hooge Raad of the Netherlands, for reasons of public policy, has denied recognition to Canadian gold clause abrogation even though the Netherlands herself had, at that time, abrogated gold clauses. ${ }^{93}$

The vagueness and triteness of the public policy concept has perhaps exerted some general influence upon the course of the courts. A student once declared: "I have believed so far that 'public policy' is a phrase for 'empty heads.' " Of course, the student was thinking of class occurrences where a professor would question a student on the rationale of a decision and the student, unable to find a specific answer, would take refuge in "public policy," and then, perhaps, be called an "empty head" by the questioning professor. It is the affirmative or interpretative use of "public policy" which, through its looseness and ubiquity, has brought that concept into disrepute. A terminological, or perhaps psychological difficulty affecting all uses of the term has been created thereby, which does not exist to the same extent in Continental doctrine. The corresponding term of ordre public, ${ }^{100}$ customary also outside the French language countries, is not employed in the interpretative sense. The "contract use" of ordre public is historically important, but has actually become insignificant. ${ }^{101}$ The result is that ordre public has become more or less a technical term of private international law, easily fitting into the fabric of juridical thought. It lacks, so to speak, the peculiar triteness of the public policy phrase.

Nevertheless, the basic vagueness of the conflicts-use of public policy and of ordre public is the same, and it is particularly this vagueness which has led American writers to oppose the conflicts-use of public policy. ${ }^{102}$ But public policy, in its conflicts sense, is no more vague than many generally accepted legal concepts. Public policy does not mean the politi-

99. In the case cited stipra note 75.

100. See Husserl, Public Policy and Ordre Public (1938) 25 VA. L. Rev. 37.

101. According to Art. 6 of the French Civil Code, which is the last of the important Preliminary Provisions of the Code, laws concerning "lordre public et les bonncs mocurs" cannot be impaired by private agreement. From this foundation of the contracts-use of ordre prblic, the latter term was carried over to private international law. It has since almost disappeared from the province of contracts. E.g., PLAviol-RIPERT, TRArte Elexinentatre de Drort Cint (12th ed. 1935), the leading textbook on French civil law, excelling also in completeness and accuracy, refers rather briefly to ordre public in the first part (vol. 1. Les Principes Genéraux 2. Théoric Ginkirale des Actes Juridiques, $\$ \$ 291,292$ ) and does not mention it at all in the chapter on contracts (vol. 2): there is an isolated reference to ordre public in the chapter on family law, vol. $2, \S 1646$.

102. Beach, Uniform Interstate Enforcement of Vested Rights (1918) 27 YALE L. J. 656; Lorenzen, Territoriality, Public Policy and the Conflict of Laus (1929) 33 Y YLE L. I. 736, 747; Nutting, Suggested Limitations of the Public Policy Doctrine (1935) 19 MInN. L. Rer. 201 ; Goodrich, Foreign Facts and Local Fancies (1938) 25 V.. L. Rer. 26. 
cal views of the individual judge or of a political party. It is "the manifest will of the state" ${ }^{103}$ and has always been understood in this sense by the courts. True, mistakes and inconsistencies in the use of the public policy concept have occurred, but not to such an extent as has been supposed. ${ }^{104}$ Whatever the vagueness and inconsistencies of public policy, they cannot sufficiently explain the attitude of the English and American courts.

The decisive factor must be sought in the liberal tradition of the common law courts, which has won definite shape in the century between the Napoleonic and World Wars. Liberalism postulates internationalmindedness favorable to the recognition of foreign law; but also, in accord with the doctrine of the division of powers, it strives to keep courts clean of anything that smacks of politics $;^{\mathbf{1 0 5}}$ and there is an element of foreign politics in the conflicts-use of public policy. ${ }^{100}$ Those liberal

103. Jacovay v. Denton, 25 Ark. 625, 634 (1869); Chaffee v. Farmers' Cooperative Elec. Co., 39 N. D. 585, 160 N. W. 616 (1918). See also Russian Socialist Federated Soviet Republic v. Cibrario, 235 N. Y. 255, 139 N. E. 259 (1923).

104. Among the American critics of public policy, Nutting is the most specific in this respect (loc. cit. supra note 102, at 199, nn. 16-20). His instances, however, are few and inconclusive. He states that in Aksiairnoye Obschestuo A. M. Luther v. James Sager, [1921] $3 \mathrm{~K}$. B. 532, the opposite result was reached as in Vladikokasvsky Ry. v. New York Trust Co., 263 N. Y. 369,189 N. E. 456 (1934). In the English case, a Russian frm, "nationalized" under Soviet law, brought suit against the English importer of wood sold to him by the Soviets from the stock of that firm. The suit was dismissed. In the New York case the claim of the nationalized Russian firm for its New York bank dcposit was allowed. In the first case the wood had been confiscated in Russia, and the defendant claimed ownership. The respective adjudications are not irreconcilable. Nutting further refers to Gooch v. Faucett, 122 N. C. 270,29 S. E. 362 (1898); Flagg v. Baldwin, 38 N. J. Eq. 219 (1884) ; Saxby v. Fulton, [1909] 2 K. B. 208, as reflecting the confusion in gaming cases. The two American cases are in accord, denying for reasons of public policy enforcement to foreign gaming contracts valid under their own law. The English case allows a claim based on a foreign loan made for the purpose of being used in gaming, which is a question different from the enforcement of a gaming contract as such; the main ground of the decision being a restrictive amendment, unknown to North Carolina and New Jersey law, to the English Gaming Act. The remaining instances are preferred by Nutting only to show that within the New York jurisdiction conflicting definitions of public policy have been advanced. This would not amount to much; but it is even questionable whether there is a conflict or rather a mere variety of definitions.

105. The common law court's dislike of political entanglement was impressively enunciated by Parker, B., in Egerton v. Brownlow, 4 H.L.C.I. 123, 10 Eng. Rep. 408 (1853) (regarding public policy), and by Hamersley, J., in Fischer v. Fielding, 67 Conn. 91, 34 Atl. 714 (1895) (regarding reciprocity in the enforcement of foreign judgments). Both utterances are from parts of minority opinions, but the dissents within the courts did not bear upon the point before us.

106. The Reichsgericht has repeatedly pointed out that there is a staatspolitisches element in judicial determination of public policy. Judgments of March 21, 1905, 60 Entscheidungen in Zivilsachen 296,300; (March 21, 1905) JURISTISCHE WocHenscurist 321; $1928 \mathrm{id}$. at 2041. This acknowledgment is all the more remarkable since German tradi- 
doctrines are an adequate expression of political conditions of the Victorian era, and they may possess an ultimate validity. Their materialization, however, presupposes the presence, on the opposite side, of a similar spirit, lest liberalism result in sheer profit for the illiberal, and in scorn to the generous. Practicing liberalism becomes preposterous where it is exercised towards a foreign law which is plainly directed against the interests of the forum.

The existence of German and other foreign exchange-control is illustrative. As was pointed out, ${ }^{10 \bar{t}}$ American courts are inclined to deny protection to the injured creditor unless there is an American place of payment or an agreement as to the applicability of American law. It was likewise shown that the place of payment carries little weight from a realistic point of view which should certainly prevail in matters of public policy.

The objective of exchange-control legislation, say that of Ruritania. to employ Lord Kinnon's term, ${ }^{108}$ may be briefly described as follows: $:^{103}$ Ruritania is badly in need of foreign exchange, her own currency is depreciating. Thus, she forbids Ruritania residents to make payments abroad, on debts or otherwise, except on government permit which will be granted only in very exceptional cases, and all foreign money held or acquired by Ruritania residents must be delivered to the Ruritania central bank, in return for depreciated Ruritania money. This machinery is directed against foreign creditors of Ruritania residents, who will at best receive satisfaction in "blocked" Ruritania accounts, the use of which depends on the whim of Ruritanian authorities. The injury, and the intended injury, to creditor countries of Ruritania, say to the United States, is obvious, regardless of such legalistic distinctions as to the "place of payment." In view of German exchange-control, the Swiss Federal Court has intrepidly declared it to be "detrimental to Swiss national economy" and a "spoliative encroachment upon creditors rights." 110 And the American government has repeatedly and in strongest terms protested against German exchange-control, ${ }^{111}$ thus giving documentary expression to American public policy on this question.

Nevertheless, one need not take so extreme a view as to assert that Ruritania's exchange-control should never be recognized. Where a foreign

tion even more than Anglo-American stresses the absence of political components in the work of the judiciary. The paramount position of the monarch in the political field is an important element in the German tradition.

107. See p. 1042 supra.

108. In the Kleinwort case, supra note 76 , at 816 .

109. A more detailed analysis may be found in Nussbuus, op. cif. supra note $\mathbf{8 5}$, at 475 ct seq.

110. Judgment of October 8, 1935, Amtliche SammIung der Entschcidungen, 61 II 242,248 .

111. 5 SEC Rep. oN Protectrve an Reorgaxiz.ition Cosar. (1937) d21 d seq. 
resident brings suit against a Ruritanian only in order to secure a more favorable jurisdiction, no interest of the forum obviating the application of Ruritania law is ascertainable. Such a holding was properly made by a lower Swiss court in a suit brought by a Lichtenstein corporation against its German debtor. ${ }^{112}$ Yet where suit was brought on a German loan bond payable in Germany, the Swiss Federal Court found adequate justification for the preference of Swiss public policy over German exchangecontrol in the fact that a fifth of the loan had been floated in Switzerland. ${ }^{113}$ In fact, any mentionable economic interest of the forum will suffice.

This also applies to the case where the creditor is a resident of the forum. Again, a Swiss court has recognized that a Swiss domicil and the presence of the German debtor's assets in Switzerland warrant resort to public policy. ${ }^{114}$ In the $W$ erfel case, the New York court was impressed by the fact that the creditor had moved into this country subsequent to the making of the contract. Perhaps there would be merit in such a view where a creditor has moved from Ruritania to the forum on his own whim. But where he has left Ruritania involuntarily and through no fault of his own, no reason exists for withholding from a lawful resident of this country the fullest protection of American law. What the creditor demands is payment of his debt. If the debtor is compelled to pay what he owes, no damage is inflicted upon him. ${ }^{115}$ The interest of the forum is better safeguarded by employing the Ruritanian's assets for the satisfaction of a resident creditor, than by allowing the assets to be withdrawn from the forum and to be delivered to the Ruritanian government, such withdrawal being possible at any moment under the system of exchangecontrol. Perhaps the Ruritanian government needs foreign exchange in order to prepare a war against the country of the forum. The court cannot know. The interests of its lawful resident should be nearer to the forum than the interests of the Ruritanian government.

112. Commercial Court of Berne, Feb. 23, 1939, 41 Institur JuRIdrove InTERNATroNal BULL 95. The court makes also the point that Swiss public policy was invoked by the plaintiff in the prosecution of its speculative purposes.

113. Judgment of Feb. 1, 1938, Antliche Sammlung der Entscheidungen, 64 II 88, 104. The fact that a Swiss corporation was the plaintiff, was not taken into account by the court, because it had been asserted, it seems, that the plaintiff was only a shield for a foreign party in interest.

In the judgment cited supra note 75 , the Hooge Raad resorted to Dutch public policy though the German bond sued upon did not indicate a Dutch place of payment. The loan, however, had been floated in Holland, and the German issuer had obligated himself towards the Amsterdam Stock Exchange to create within Holland facilities for the payment of the bonds and coupons.

114. Superior Court of Zurich, March 1, 1939, in Thorsch v. Thorsch (not yet published).

115. Werfel v. Böhmische Escomptebank, N. J. L. J., July 20, 1939, p. 161. The Holzer case, supra note 31, offers a different problem inasmuch as damages for breach of contract were claimed. 
With regard to German-American relations, another point must be added. Germany has expelled and is still expelling many of her citizens and stripping them of their property for purely political reasons. ${ }^{110}$ The attempt of the German government, despite all this, to extend foreign exchange-control to those expelled is particularly shocking. This country, however, has made it its publicly announced policy to offer a haven to the expelled. ${ }^{117}$ From the other side of the ocean, the view has sometimes been voiced that the very test of humaneness is to take care of the distressed without their property, leaving the latter to the country which does not feel bound by humanitarian canons. American courts are unlikely to adopt such views. Obviously, the objectives of declared American policy will be better served if enforcement of debts owed to refugees is granted by American courts through realization of American assets of the refugee's debtors.

One can perfectly well understand that the diverse Ruritanians are strongly interested in making their exchange-control effective beyond their frontiers. Still this should be done by treaties such as have been concluded in a great number of cases. As has been pointed out elsewhere, ${ }^{118}$ it is not for the courts unilaterally to bind their governments in the name of alleged conflict of laws theories.

In conclusion, it may not be amiss briefly to examine the use of public policy by foreign courts in cases where the forum at the time of the decision had itself impaired contracts through adoption of exchangecontrol and similar measures. Apart from the 1939 decision of the Dutch Hooge Raad, ${ }^{119}$ there seem to be only German examples. Their summary will further illustrate the view that particular restraint in the use of public policy is not warranted in the face of foreign measures of the type mentioned.

As early as $1923,,^{120}$ the Reichsgericht held valid a contract, made in 1917, in Petrograd, between Russian subjects which provided, in the

116. Under a law of Dec. 12,1938 , Reichsgesetzblatt 1938 I $1733, \$ 55$, preceded by a similar decree of Dec. 1, 1935, Reichsgesetzblatt 1935 I 140S, a German emigrant remains subject to restrictions, prohibitions and duties in respect to things regarding which he had been subject to such restrictions, prohibitions and duties before his emigration. This provision may, however, be material in litigation between emigrants. Nusspius, of. cif. supra note 90 , at 497, n. 42 .

117. See, e.g., Dep't of State, (1938) Press Rcleases, p. 411 [of March 24, 1938, tal:ing the initiative for the Evian Conference], p. $\$ \& 6$ [of Mfay 16, regarding President's Advisory Committee on Political Refugees]. This policy developed subsequently to the decision of the Holzer case. As rightly suggested in (1938) 3S CoL. L. REv. 1490, 1403, n. 19 , it is not impossible that in a forthcoming similar case the new policy may influence the view of the court.

118. Nussbauar, op. cit. stpra note 90 , at 493 , giving instances of pertinent treaties at 507 et seq.

119. See note 75 supra.

120. At that time there had been exchange control, though in a mild form, in Germany since 1919. Nussbaum, Das Geld ix Theorie ano Praxis ues Deutsche: usio AUSLÄNDISCHEN RECHTS (1925) 257, n. 2. 
teeth of Soviet exchange-control, a payment abroad. Foreign exchangecontrol legislation was disregarded by the court for reasons of public policy, the parties having meanwhile settled in Germany. The court read into the contract a tacit agreement to the effect that the debt should be payable at the place of the first non-Russian settlement of the parties, thus securing a German "place of payment" as a further local "contact." Here we have non-recognition of foreign (Russian) exchange-control in an entirely foreign transaction, the only real contact with the forum being the new German domicil of the parties. ${ }^{121}$ Hungarian exchangecontrol law was judicially denied recognition for reasons of German public policy in the case of a bill of exchange drawn in Germany by a transient Hungarian on Budapest in terms of American dollars. The Budapest drawee, because of Hungarian exchange-control, did not pay dollars. Upon redemption of the bill, a German endorser brought suit against the drawee. Referring to German public policy, the court gave judgment to the plaintiff. ${ }^{122}$ Here again, the contacts with Germany were slight. They were more substantial in the case of a Fungarian mortgagor of German real estate who was prevented by Hungarian exchange-control from discharging his debt in Germany. The appellate court of Berlin, ignoring the Hungarian prohibition, refused to grant the debtor respite under the German moratorium law. ${ }^{123}$ American gold clause abrogation was involved in a Reichsgericht case where suit was brought against a German public corporation on dollar bonds issued in New York and subjected to New York law. Gold clause abrogation was denied recognition in this case, provided the bonds were held by German residents. ${ }^{124}$

Thus it appears that the German courts are reluctant to enforce foreign exchange-control laws and gold clause abrogation, without confining themselves to a narrow place-of-payment theory.

\section{Public Policy in Interstate Relations}

In the interstate field there is considerable authority to support the view that there is, or should be, no place for the use of the public policy

121. Judgment of Oct. 3, 1923, 108 Entscheidungen des Reichsgerichts in Zivilsachen 241. Id. Reichsgericht, Oct. 3, 1928, (1928) JuRISTISChe Wocrenschrift 1196, and Appellate Court of Berlin, April 1, 1926, 1926 id. at 2002. Contra: Appellate Court of Hamburg, May 16, 1929, (1930) Hanseatische Rechts-Und GerichtszeitschiritT B. 743. In the judgment of Dec. 13, 1929, (1930) W ARNEYERS RecritspRECHung 78, the Reichsgericht interpreting a very similar situation in a different way used Russian exchange control law. From the angle of the above discussion, however, it is remarkable that in this case the plaintiff had abandoned his German domicil prior to the bringing of the suit.

122. Court (Landgericht) of Berlin, Feb. 19, 1932, (1932) Juristische WocheNSChRIFT 2306; (1933) 28 INSTitut JURIDIQUE INTERNATIONAL BULL. 84.

123. Decree of Oct. 10,1932, (1932) Juristische Wochenschrift 3773, with approving annotation by the present writer.

124. Judgment of May 28, 1936, (1936) JuRistische Wochenschritt 2058. 
argument. Nearly all of the American writers who have discussed the question ${ }^{125}$ tend towards this view. Dean Goodrich postulates that in the interstate area public policy should be "cast out altogether." It has even been judicially asserted, in a minority opinion, that the differences among the laws of the several states "relate to minor morals of expediency and debatable questions of internal policy."120

The courts, however, have not followed the course suggested. In Bradford Electric Light Company, Incorporated i'. Clapper, the Supreme Court, in extending the full faith and credit clause to state statutes, expressly exempted the case of an adverse public policy of the forum, ${ }^{12 \pi}$ and this reservation was reiterated in Pacific Employers Insurance Company a'. Industrial Accident Commission. ${ }^{128}$

So long as one contemplates the problem of interstate public policy in the abstract, everything seems to speak in favor of the critics. The desirability of having a uniform law throughout the United States and of eliminating the sources of discord is so manifest that any discussion almost appears to be a waste of time.

The picture, however, changes if one tackles concrete situations as suggested by actual cases. Suppose that forum $F$ has declared lottery contracts unlawful, and an $F$ resident and citizen enters into a lottery contract in $X$ where such contracts are valid. ${ }^{129}$ Why should $F$ be compelled, in a suit by or against that resident, to subordinate its policy to the policy of $X$ ? Or suppose that $F$ has comprehensive small-loan legislation which limits interest to two and one-half per cent monthly, and an $F$ resident is a party to a small loan contract involving a higher rate of interest. but made and to be performed in $X$ where higher interest rates are permitted. ${ }^{130}$ Would not enforcing the higher rate of interest in that case invite evasion and jeopardize the success of $F$ 's small-loan legislation? Or X's bank legislation favors depositors in the case of a bank's insolvency to such an extent that not much will be left to other creditors. If the courts of $F$, because of a divergent public policy, disregard that privilege in wholly $F$ transactions with regard to forum prop-

125. See note 102 supra. Stranberg. of. cit. supra note 11, at 152, more reservedly remarks that the courts "should confine local public policy within narrow limits."

126. Crouch. J., in Mertz v. Mertz, 271 N. Y. 466,475 ; 3 N. E. (2d) 597,600 (1936).

127. 286 U. S. 145 (1932).

128. 305 U. S. 563 (1939). The restriction imposed upon the state courts by the Bclmont case, p. 1046 supra, is different in character. And of course state public polic is ineffective in the face of divergent federal legislation. MLondou v. New York, N. H. \& H. R. R., 223 U. S. 1 (1912).

129. See Watson v. Murray, 23 N. J. Eq. 257 (1872).

130. See Personal Finance Co. of Council Bluffs v. Gilinshy Fruit Co., 127 Neb. 450, 255 N. W. 558 (1934), cert. denicd. 293 U. S. 627 (1935); Continental Adjustment Corp. v. Klause, 12 N. J. Misc. 703, 174 Atl. 246 (D. Ct. 1934) ; Folsom v. Continental Adjustment Corp., 48 Ga. App. 435, 172 S. E. 833 (1934). 
erty of the bank, ${ }^{131}$ ought such a course to be condemned simply as local fancy? Or where the $F$ law grants to injured workers more liberal compensation than does the $X$ law, and the injury of an $F$ worker happened in $X$ and would under general conflict rules be judged according to the law of $X$, should the $F$ courts be prevented from applying the better local scale of compensation for no other reason than bias against the public policy doctrine? ${ }^{\mathbf{1 3 2}}$

In Mertz v. Mertz, ${ }^{133}$ a good phrase was suggested to describe the appropriate function of public policy in conflicts situations. As will be remembered, in that case a New York wife had brought suit against her husband according to Connecticut law and the court, rightly or wrongly, examined the situation from the angle of public policy. Conceding as a matter of argument that New York disallowance of such suits is outdated, Judge Lehman stated that the courts should not "transform an anachronism into an anomaly." ${ }^{134}$ Avoidance in the administration of the law of "anomalies" originating in an improper use of foreign law is an objective which expresses rather adequately the function of public policy in the interstate as well as in the international area.

Disturbing though the constitutional theory of delegated powers and the ensuing multitude of state laws might appear in the light of recent developments, elimination of the public policy rule in interstate relations would hardly be a proper means to overcome present difficulties. The result of such elimination would be to intensify existing and inevitable discrepancies by injecting them into the inner economic and social setting of the states. And it cannot be maintained that the trend is towards lessening those discrepancies. State legislative experimentation is going on and may be extended in the future. ${ }^{135}$ Opportunity of territorially limited experimentation has been recommended as one of the advantages of the American constitutional system. The public policy rule operates as a guarantee that such experimentation will not affect the "sphere of interest" of other states; a guarantee independent of conflict of laws rules which assign the cases to the several legal systems from an entirely different angle.

The preceding views find strong support in the Alaska Packers and Pacific Employment Insurance cases. Since in these cases the California legislature was held empowered to extend the operation of the California

131. See Washington Alaska Bank v. Dexter Horton Nat. Bank, 263 Fed. 204 (C. C. A. 9 th, 1920).

132. The negative answer seems to be authorized by Pacific Employers Ins. Co. v. Industrial Accident Comm., 305 U. S. 563 (1939).

133. 271 N. Y. 466,3 N. E. (2d) 597 (1936).

134. Id. at 474,3 N. E. (2d) at 600 .

135. See De Courcy, State Trade Barriers to Interstate Commerce in 2 Conparative LAW SERIES (Dep't of Commerce 1937) 172. 
Workmen's Compensation Act to cases which under ordinary conflict of laws rules might have come within the range of other than California law, there is no obligation or principle generally withholding from the state courts a similar power based on the public policy rule. It is only the Constitution which furnishes checks against unsound territorial expansion of state law; ${ }^{136}$ "checks" rather than "boundaries" because the laws of the several states may overlap each other, as is made clear in the Pacific Employment Insurance case.

Because of the constitutional implications of the matter, the comparative approach is not particularly helpful in the situation. However, a German pre-war instance, originating in the diversity of state lavs under the 1871 constitution, may be mentioned. The Prussian mother of an illegitimate child of eleven years, mother and child being Prussian nationals and Hamburg residents, wished to have the child educated in the Protestant religion, contrary to the wish of the child's guardians. But Prussian law, applicable according to Hamburg conflicts rules, did not permit a change of the child's religion prior to his fourteenth year. Nevertheless, the appellate court of Hamburg discarded the Prussian provision as contrary to religious freedom guaranteed by the Hamburg Constitution. ${ }^{137}$

The case suggests that the public policy problem in interstate relations may assume a grave political character. One may recall the tensions in the interstate field relating to the slavery situation. ${ }^{133}$ Similar strains, fortunately, no longer exist among the several states. However, fascist tendencies have temporarily prevailed in one state. Also from a political point of view, it would be unwise definitively to lay down the public policy weapon only to satisfy a theory.

136. See Allgeyer v. Louisiana, 165 U. S. 578 (1897); New York Life Ins. Co. v. Dodge, 246 U. S. 357 (1918) and other cases not to be discussed here.

137. Reichsgericht, judgment of Sept. 25, 1913, Hanseatische Gerichtszeitung. Beiblatt 1914, n. 235. The Tribunal Civil of Libourne, in a judgment of February 24, 1921, Revoe JURIDIQUE DE L'ALSACE ET DE LORRAINE 391, was concerned with a suit brought on behalf of an Alsacian minor against his illegitimate French father for alimony on the basis of the German law, maintained as "local law" by the French legislation suhsequent to the Treaty of Versailles. The defense that the claim was contrary to French public policy was rejected by the court on the ground that the "local law" was to be considercd as "veritable French law." No other pertinent continental cases are known to this writer, but the two mentioned indicate that the public policy problem in so far as it originates in a diversity of local law systems within the same politieal unit, ean only be solved with an eye to the political structure of that unit and of the territorial segments thereoi which are endowed with a legal system of their own. For a general discussion. sce Eulesco, ESSAI SUR LES CONFITTS DE LoIS (1925) 71, 72, and Knapp, sipra note 56, at 159.

138. See, e.g., Minor v. Cardwell, 37 11o. 350 (1866) ; Jocervy v. Dunton, 25 Arls 623 (1869). The Dred Scott case, 19 How. 393 (U. S. 1854) was not decided on conflicts grounds, but the problem before us was clearly presented. 


\section{Public Policy and Foreign Judgments}

It is a universally recognized principle that a foreign judgment will not be accorded recognition if a public policy of the forum would thereby be violated. ${ }^{139}$ Application of a foreign legal system is not directly involved in this situation. The court is merely confronted with a special act of a foreign sovereignty, addressed solely to the parties in litigation. Recognition is first predicated upon technical requirements, such as proper jurisdiction of the foreign court, fair trial in that court and the existence of reciprocity. The merits of the foreign judgment will not be examined by the forum, except in so far as its public policy is challenged. Consequently, the technical requirements being fulfilled, recognition is the norm, non-recognition, because of public policy, the exception, exactly as in the choice of laws situation. Also the range of relevant public policy is ordinarily the same here and there. ${ }^{140}$ Yet there are differences.

In the international area the practical importance of the problem before us is very limited. Barring (a) divorce and other judgments on status and (b) the existence of pertinent bilateral treaties, such recognition is actually rare. A well-known obstacle consists in the prerequisite of reciprocity, enunciated by the Supreme Court ${ }^{141}$ and some of the state courts. ${ }^{142}$ Also the other requirements and the difficulties of having the foreign judgment properly authenticated have a discouraging effect.

Under such circumstances, it is not surprising that, in the international area, only one American case denying recognition to a foreign judgment for reasons of public policy ${ }^{143}$ has been discovered. The greater frequency of recognition of foreign divorce judgments did not augment the number of public policy decisions since in divorce matters the interests of the forum is focused on the question of jurisdiction. Where the spouses had their domicil in the foreign country whose courts granted the divorce, American courts, in recognizing the divorce, will not bother about the grounds of the divorce. ${ }^{144}$

139. Restatentent, Conflict of Laws (1934) $\$ 445$; Niboyet, Manued de Droit INTERnatronal Privé (1928) 932; German Zivilprocessordnung $\$ 328(1)$ (4) ; Italian Codice di Procedura Civile, Art. 941 (4).

140. In continental law there is a kindred use of public policy in connection with Letters Rogatory which on the basis of treaties or international custom must be performed, under the caveat.; moreover, that the public policy of the state applied to, will not be violated. See, e.g., 4 Lapradeile aNd Niboyet, Repertoire de Droit International (1929) 77. In this country, the matter is entirely within the court's discretion.

141. Hilton v. Guyot, 159 U. S. 113 (1895).

142. Warren v. Warren, 73 Fla. $764,793,75$ So. 35 ; Traders Co. v. Davidson, 146 Minn. 224, 178 N. W. 735 (1920) ; Northern Aluminum Co. v. Law, 157 Md. 641, 645, 147 Atl. 715, 717 (1929).

143. De Brimont v. Penniman, 7 Fed. Cas. 309 (C. C. S. D. N. Y. 1873).

144. See, e.g., GoodricH, op. cit. supra note 21 , at 340, n. 22 . 
With respect to money judgments rendered by courts of sister states, the problem of public policy possesses a much greater practical significance. It is generally believed that such judgments must be enforced within the United States even where they are utterly repugnant to the law of the forum. ${ }^{145}$ This rule is supposed to follow from the full faith and credit clause, an argument obviously unconvincing, since in the case of statutes the Supreme Court has maintained the public policy rule in the teeth of that clause. Still it is true that as a matter of sound policy enforcement of state judgments throughout the Union should be favored. For example, where the law of the forum was in terms applied, but misapprehended by the foreign court, the forum should not be allowed to deny recognition under the pretense that the judgment violates the public policy of the forum. ${ }^{140}$ The same would be true of erroneous or incomplete fact findings of the first judgment. ${ }^{147}$ Such isolated mistakes are less dangerous to the forum than disregard of its laws, and they may come under the principle that the forum, not acting in appellate capacity, must not reconsider the merits of the original decision. The American cases rejecting the public policy argument can nearly all be explained on one or the other of these grounds, ${ }^{148}$ or on the ground that the divergence of the $F$ law from the $X$ law was not "strong"

145. Restatearent, Conflict of LAws (1934) $\$ 446$; Goonrich, of. cil. sufro note 21 , at 541 .

146. This seems to be the point in Fountleroy v. Lumm, 210 U. S. 230 (1908), where enforcement of a Missouri judgment was sought in Mississippi. Said the court: "The judgment cannot be impeached in Mississippi even if it went upon a misapprehension of the Mississippi law." The Mfissouri court no doubt supposed that the award (on which the suit was brought) was binding under the law of Mississippi. Unmistalsable is MaeDonald v. Grand Trunk Ry., 71 N. H. 448, 52 Atl. 982 (1902), where the public policy defense was held not to be justified by the fact that in rendering the judgment a mistake was made as to the law of New Hampshire, especially when, as in this ease "the (original) court is led into error by the failure of the complaining party to inform it as to the foreign law."

147. This may have been the situation in Engineers Nat. Bank v. Drew, $311 \mathrm{~Pa} .59$, 166 Atl. 376 (1933). The original judgment had been rendered by an Ohio court against a wife as surety for her husband, she allegedly residing in Pennsylvania, whose laws held such sureties by Pennsylvania wives void. Perhaps the Ohio court had found, right or wrong, that she did not reside in Pennsylvania. The Pennsylvania court had no nower to go behind this statement. The same rule has been recognized in the international area, see Godard v. Gray, [1870] 6 Q. B. 138, and Nussbaum, Deutscafs Intermatmozales Privatrecht (1932) 436, n. 2 citing German cases.

148. An exception is Beal v. Carpenter, 235 F. 273 (C. C. A. Sth, 1916), where Arlannsas was compelled to enforce against her strong public policy a New York judgment upholding a contract on cotton futures. There is in the federal courts an aversion, questionable in this writer's opinion, to those state laws by which states with a less commercialized populace try to protect their residents from the effects of gambling at the stod: and produce exchanges. 
enough to warrant the use of the public policy weapon. ${ }^{140}$ Despite the sweeping language of some of the cases, it is very doubtful whether the dominant doctrine can be maintained which would entirely eliminate public policy considerations from the examination of sister-state judgments. Suppose the $X$ court gives judgment against an $F$ citizen, discarding the $F$ law (e.g., on a small-loan act), applicable under conflicts rules, as contrary to the $X$ public policy. Compelling $F$ to enforce this judgment means a preference of the $X$ law over the $F$ law to be effectuated by the $F$ courts themselves. Apart from the political impropriety involved, this course may practically result in an undermining of the $\vec{F}$ statute. There is no judicial authority for such a course. ${ }^{150}$ It may be hoped that the Supreme Court, should it become concerned with the problem, will reach a solution as just and statesmanlike as were its two last conflicts decisions on workmen's compensation.

149. This is obvious in Westwater v. Murray, 245 F. 427 (C. C. A. 6th, 1917), where suit was allowed on a Pennsylvania promissory note providing for an allowance of attorney services, a clause not permitted by the forum, but nevertheless held valid. The opinion speaks of "declared policy" rather than of "public policy" of the forum. Hicston v. National City Bank, 280 Fed. 525 (1922), may perhaps be included in this group. The situation was similar as in the Drew case, supra note 147, where the wife's residence was not indicated. Suppose the residence was outside the forum, no strong public policy of the latter could have been involved.

150. As to Fountleroy v. Lumm, see note 146 supra. 